flaged by the similarity of colour to the lichens which grow on the tree. If the spider is disturbed, however, a vivid red streak shoots down the trunk, as it jumps and lowers itself on a thread. The red streak stops as it alights further down the trunk with the underside of the abdomen covered. It is very difficult to follow the later part of this movement, owing to the rapid colour change. Many members of the Eresidae, which retreat into their tube-like web endings when disturbed, jump when further attacked, and the same effect is produced by the highly coloured underside of the abdomen. It would appear that this colour change would once again offer protection against a foe attacking at close range."

\section{Parliamentary and Scientific Committee}

THE annual report for 1944 of the Parliamentary and Scientific Committee refers to a further increase in the subscribing membership and to the formation of a Parliamentary Action Sub-Committee, which was especially active in connexion with the Finance Bill clauses relating to research. The report includes a summary of the changes recommended by the SubCommittee on Taxation and Research and of the proposals of Sir John Anderson in his Budget speech last April, as well as of points made to elucidate these proposals during the debate. The principal recommendations in the report on Scientific Aspects of British Agricultural Policy and in the Memorandum on the Organisation and Development of Research in Great Britain issued by the Committee during the year are detailed in the report, which further refers to the preparation of a confidential memorandum on scientific attachés, and to steps taken to encourage the establishment in the Dominions of committees similar to the Parliamentary and Scientific Committee.

\section{$X$-Rays in Engineering and Inciustry}

A PAPER on this subject read before the Institution of Electrical Engineers in London on February 1 by Dr. V. E. Pullin outlines the development of Xradiography in industry and engineering from the time of Röntgen's discovery in 1895. In the first section, developments in uses and equipment up to the beginning of the present War are recorded in broad outline. In the second, the war-time development of engineering and industrial radiography, particularly with regard to Service requirements and inspection, is dealt with. The third section forecasts future radiographic developments in connexion with modifications in engineering inspection and development. The author also foreshadows the trend of development in X-ray apparatus and equipment. Applications of $\mathrm{X}$-ray crystal analysis in industry and the enormous progress made by radiology in the medical and surgical fields are not discussed.

\section{The Night Sky in March}

New moon occurs on March 14d. 03h. 5lm., U.T., and full moon on March 28d. 17h. 44m. The following conjunctions with the moon take place: March 11d. 21h., Mars $2^{\circ}$ N. ; March 16d. 10h., Venus $12^{\circ}$ N. ; March 21 d. 03h., Saturn $0 \cdot 4^{\circ}$ N.; March 27d. 05h., Jupiter $3^{\circ} \mathrm{S}$. During March no occultations of stars brighter than magnitude 6 take place. Mercury is close to the sun at the beginning of the month, rising about 20 minutes after, and setting 10 minutes before, the sun then. At the end of March the times of rising and setting are $5 \mathrm{~h} .47 \mathrm{~m}$. and $20 \mathrm{~h} .09 \mathrm{~m}$. , respectively. The planet attains its greatest easterly elongation on March 26. Venus is a very conspicuous object in the western sky and is well placed for observation; setting at $21 \mathrm{~h}$. $54 \mathrm{~m}$. and $21 \mathrm{~h} .04 \mathrm{~m}$. at the beginning and the end of the month, respectively. Venus attains its greatest brilliancy on March 10. Mars, a morning star, is too close to the sun for favourable observation. Jupiter moves from the constellation of Virgo into the constellation of Leo during March, and can be seen throughout the night, setting at $7 \mathrm{~h} .26 \mathrm{~m}$. and $5 \mathrm{~h} .17 \mathrm{~m}$. on March 1 and March 31 . The planet is in opposition to the sun on March 13. Saturn, in the constellation of Gemini, sets at $3 \mathrm{~h} .47 \mathrm{~m}$. and 1h. $53 \mathrm{~m}$. on March 1 and March 31 , and is stationary on March 5. Vernal equinox is on March 21d. $00 \mathrm{~h}$.

\section{Announcements}

THe Committee of the Athenæum has elected the following, under the provisions of Rule II of the Club, which empowers the annual election by the Committee of a certain number of persons of distinguished eminence in science, literature or the arts, or for their public services: Prof. Sydrey Chapman, chief professor of mathematics, University of London; Sir Reginald Coupland, Beit professor of Colonial history, University of Oxford ; Sir George Stapledon, director of the Grassland Improvement Station, Ministry of Agriculture and Fisheries, Stratford-on-Avon.

Dr. T. McKeown has been appointed to the chair of social medicine in the University of Birmingham. Dr. McKeown, a former Rhodes scholar, has been demonstrator in biochemistry at McGill University, Poulton research scholar and demonstrator in physiology at Guy's Hospital, London, and research worker in charge of Field Social and Economic Survey, Research and Experiments Department, Ministry of Home Security.

The Board of the Institute of Physics has authorized the formation of a South Wales Branch of the Institute which is to be centred at Swansea. The inaugural meeting of the Branch will take place at 2.30 p.m. on March 10 in the Physies Department of University College, Swansea, when Dr. C. Sykes, principal of the Brown-Firth Research Laboratories, Sheffield, will deliver an illustrated lecture on "Physies in Metallurgy". Visitors will be welcome ; admission is free and without ticket. Further particulars of the Branch can be obtained from the Acting Honorary Secretary, Dr. T. V. I. Starkey, Technical College, Mount Pleasant, Swansea.

UNDER the title of "Medical Miscellany List K", Schuman's, of 20 East 70th Street, New York, has recently published an annotated catalogue of more than seven hundred items on various medical subjects and an appendix with more than a hundred and fifty early American inaugural theses. While all branches of medicine are represented, the subjects chiefly dealt with are anatomy, biography, epidemiology, materia medica, history of medicine, neurology and psychiatry, pathology, physiology, surgery and therapeuties. Special mention may be made of the following books : Charles Etienne's work on anatomy (1545), a French translation of Fracastorius' poem on syphilis (1753), Stephen Hales' "Statical Essays" (1731), Florence Nightingale's "Notes on Nursing" (1860) and Allwoerden's "Life of Servetus" (1728). 